\title{
Water quality assessment and control efforts use the pollution index method in the Sikendil river
}

\author{
Ade Lenty Hoya*, Yuliastuti Nany, Sudarno Utomo, and Andrea Ramadhani Maharlika \\ Program of Environmental Science, School of Post-Graduate, Diponegoro University, Semarang- \\ Indonesia
}

\begin{abstract}
Water is one of the primary needs of living things. Everyday human life needs water from drinking water consumption, water recreation, animal husbandry, and agriculture. It is important to monitor water quality in water bodies so that they can be used properly. The goal is to find out water quality in Sikendil River, Klepu Village, Pringapus District, Semarang Regency, and Pollution control efforts undertaken by stakeholders. Water quality will be assessed using the Pollution Index Method, pollutant Physical, Chemical, and Biological parameter test results compared with quality standards in government regulations No. 82 of 2001. Samples were taken at the ordinate point S: 07010 '52.7 "E: 1100 26' 52.2 ". Secondary data from the Semarang Regency DLH lab test results in 2019. The result is that the parameters exceed the quality standards of nitrate, nitrite, free chlorine, and COD. Water quality was in the Polluted category for the water class I, II, and III designations at 9.50, 9.41, and 9, 35. The status of Medium Pollution in water class IV is 1.66. Consistency, supervision, counseling, and periodic reporting are needed between stakeholders
\end{abstract}

Keyword: Water quality monitoring, Pollution Index (IP) Method, Water Pollution Control

\section{Introduction}

The existence of water is affected by the threat of environmental disasters, land use, geopolitical conflicts, contaminants, and population growth [1]. The water used is following its designation is an excellent way to find out the quality level of water quality so that it is suitable for consumption or use in daily human activities or not. In addition to knowing the water quality can be evaluated in the form of suggestions and take action when pollutants reduce water quality [2].

*Corresponding author: hoyaadelenty@gmail.com 
Sikendil River is a river in the Klepu Village, Pringapus District, Semarang Regency. Around the river, there are industrial, residential, and agricultural activities. The water designation of the Sikendil river is not yet determined. The river water is usually used by residents to irrigate crops around the river containing maize, cassava, and peanuts. Initially, water quality was intended for drinking water, but it has increasingly been developed and can be used to assess the use of all types of water [3]. River water flow produces pollutants faster than puddles [4].

This method equally evaluates water quality by comparing the test results with the standard parameters of its pollution quality. In Indonesia, water quality assessment is generally carried out by the IKA. Method using the pollution index (IP) method and Store, which is dominantly used in Indonesia. The calculation uses the STORET and IP Method, the water quality standard consisting of 4 classes of raw water [5]. These two methods cannot be compared directly because of the different data requirements and the different ways of calculation. If you want to know the quality of river water using monitoring data that is minimal based on frequency, it is better to use the Water Pollution Index (IP) [6].

Water quality inquiry using the pollution index method. Relative pollution levels can be detected by this method, can also be a known amount of pollution in some or all rivers. Pollution index coverage is a meaningful and independent parameter. Method of comparing the results of contamination with quality standards. The pollution index uses a single data that indicates the current results only [7]. Based on Ministerial Decree no. 115 of 2003, the results of calculations using the Pollution Index method will be compared with the status of water quality following the quality standards specified in Government Regulation No. 82 of 2001. Pollutant indexes are affected by the number of parameters (some parameters do not meet quality standards) and are not sensitive enough in differentiating classes to find out the amount of contamination at each location and when taking samples [8].

\section{Materials and Methods}

This research uses descriptive research with a combination of research methods or mixed methods study. Is a combination of qualitative and quantitative [9] and collects data using secondary data derived from laboratory test results of the Semarang Regency Environmental Office, interviews with the Department of the Environment, surrounding communities, and farmers, as well as documentation. Water samples are taken at one point at the ordinate point 07010 '52.7 "E: 110026 ' 52.2" because they represent water samples based on physical characteristics such as odor, taste, and color that change, taken in the Klepu village, Pringapus sub-district, Semarang Regency using the packaging plastic bottles to collect water samples. The river sampling point can be seen in Figure 1. 


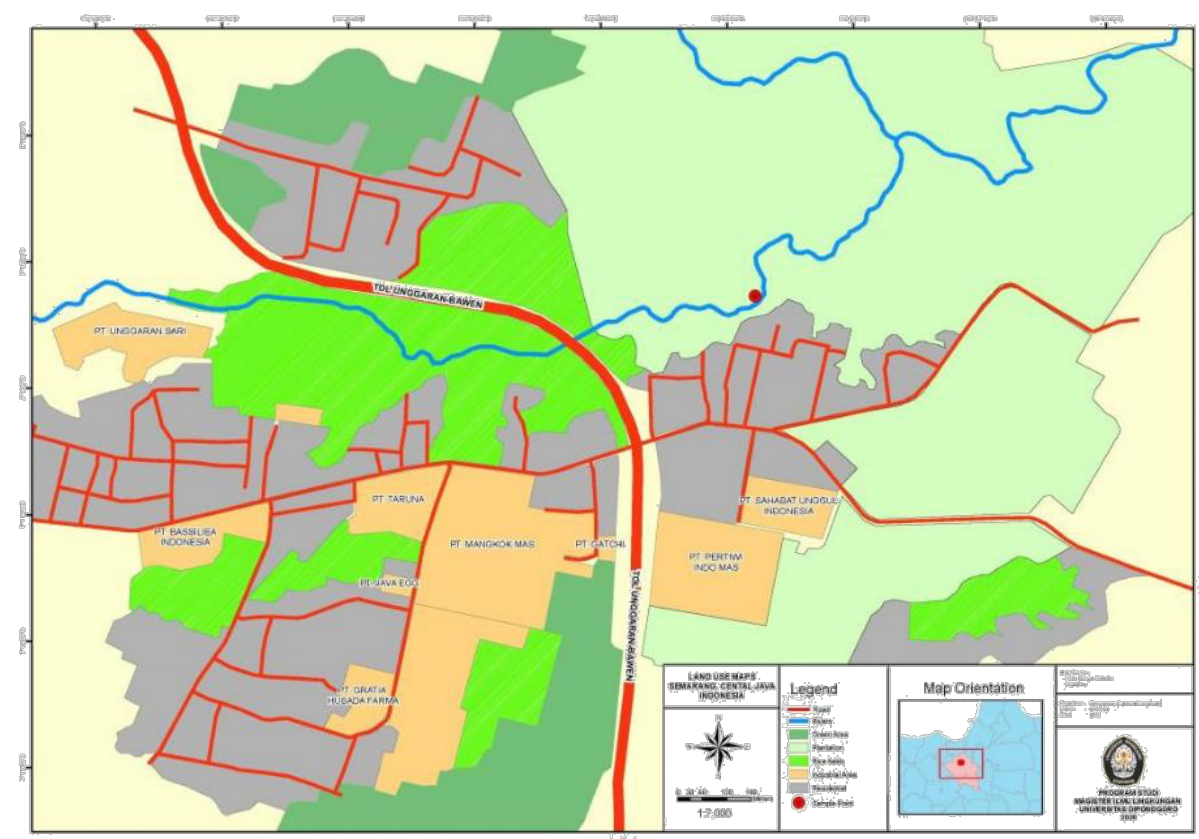

Fig. 1. Map of Sikendil River

This study uses the Pollution Index (IP) method by comparing the results of laboratory tests with water grade quality standards that exist in government regulation No. 82 of 2001.

$$
\mathbf{P i}_{\mathbf{j}}=\frac{\sqrt{\left(\frac{C i}{L i_{j}}\right) 2 M+\left(\frac{C i}{L i_{j}}\right) 2 R}}{2}
$$

\section{Information:}

$\mathrm{Li}=$ Water quality standards

$\mathrm{Ci}=$ Sample measurement results

Pij $=$ Pollution Index

Then included in the evaluation range category of river pollution according to Minister of Environment Decree No. 115 of 2003. Evaluations of PI scores are:

$$
\begin{array}{ll}
0 \leq \mathrm{PIj} \leq 1.0 & =\text { Good condition } \\
1.0<\mathrm{PIj} \leq 5.0 & =\text { Moderately Polluted } \\
5.0<\mathrm{PIj} \leq 10 & =\text { Polluted } \\
\mathrm{PIj}>10 & =\text { Extremely Polluted }
\end{array}
$$

The maximum index (IM) indicates the dominant parameters that pollute and the average is indicated by (IR) [10]. The Pollution Index Method method, the higher the IP value, indicates the declining water quality [7]. 


\section{Result and Discussion}

\subsection{Water Quality Analysis}

Table 1. Lab Test Results for the Physical, Chemical and Biological Parameters of the Sikendil River

\begin{tabular}{|c|c|c|c|c|c|c|}
\hline \multirow[b]{2}{*}{ No } & \multirow{2}{*}{ Parameters } & \multirow{2}{*}{ Point 1} & \multicolumn{4}{|c|}{ Quality Standards Water Quality Class } \\
\hline & & & I & II & III & IV \\
\hline 1 & Suhu & 26 & Dev 3 & Dev 3 & Dev 3 & Dev 5 \\
\hline 2 & TDS & 154 & 1000 & 1000 & 1000 & 2000 \\
\hline 3 & TSS & 15 & 50 & 50 & 400 & 400 \\
\hline 4 & $\begin{array}{l}\text { Nitrate N03 Sebagai } \\
\mathrm{N} \\
\end{array}$ & 35,8 & 10 & 10 & 20 & 20 \\
\hline 5 & $\mathrm{pH}$ & 7 & $6-9$ & $6-9$ & $6-9$ & $6-9$ \\
\hline 6 & Tembaga $(\mathrm{Cu})$ & 0,01 & 0,02 & 0,02 & 0,02 & $(-)$ \\
\hline 7 & Nitrite (NO2) & 15 & 0,06 & 0,06 & 0,06 & $(-)$ \\
\hline 8 & Khlorin Bebas & 0,23 & 0,03 & 0,03 & 0,03 & $(-)$ \\
\hline 9 & Fluoride & 0,07 & 0,5 & 1,5 & 1,5 & 1,5 \\
\hline 10 & COD & 87,24 & 10 & 25 & 50 & 100 \\
\hline 11 & Total Coli & 6100 & 1000 & 5000 & 10000 & 10000 \\
\hline
\end{tabular}

Source: Semarang Regency Environmental Agency Laboratory 2019

Some parameters exceed the Government Regulation standard No. 82/2001. These parameters exceed the four water quality classes, namely Nitrate of $35.8 \mathrm{mg} / 1$, Nitrite of 15 $\mathrm{mg} / 1$. Free Chlorine of $0.23 \mathrm{mg} / 1$ means that these parameters cannot be used for drinking water, water recreation, freshwater fish farming, animal husbandry, water for irrigating crops, and other similar uses. While the COD parameter of $87.24 \mathrm{mg} / 1$ exceeds the water class III quality standard, it cannot be used as freshwater fish farming, animal husbandry, water to irrigate crops, and other similar uses. It can still be used in water class IV as irrigation and additional uses for the same. The biological parameters of Total Coli of 6100 that exceed the water quality classes III and IV mean that they cannot be used to cultivate freshwater fish, livestock, water to irrigate crops, and other similar uses. 
Table 2. Results of Water Quality Calculation Methods for Pollution Index (IP)

\begin{tabular}{|c|c|c|c|c|c|c|c|c|}
\hline \multirow[b]{3}{*}{$\begin{array}{l}\mathrm{N} \\
\mathrm{o}\end{array}$} & \multicolumn{2}{|c|}{ Water Class } & \multicolumn{2}{|c|}{ Water Class } & \multicolumn{2}{|c|}{ Water Class } & \multicolumn{2}{|c|}{ Water Class } \\
\hline & \multicolumn{2}{|c|}{ I } & \multicolumn{2}{|c|}{ II } & \multicolumn{2}{|c|}{ III } & \multicolumn{2}{|r|}{ IV } \\
\hline & $\mathrm{Ci} / \mathrm{Li}$ & $\begin{array}{l}\mathrm{Ci} / \mathrm{Li} \\
\text { Baru }\end{array}$ & $\mathbf{C i} / \mathbf{L i}$ & $\begin{array}{l}\mathrm{Ci} / \mathrm{Li} \\
\text { Baru }\end{array}$ & $\mathbf{C i} / \mathbf{L i}$ & $\begin{array}{l}\mathrm{Ci} / \mathrm{Li} \\
\text { Baru }\end{array}$ & $\mathbf{C i} / \mathbf{L i}$ & $\begin{array}{l}\mathrm{Ci} / \mathbf{L i} \\
\text { Baru }\end{array}$ \\
\hline \multicolumn{9}{|l|}{1} \\
\hline 2 & 0,15 & 0,15 & 0,15 & 0,15 & 0,15 & 0,15 & 0,08 & 0,08 \\
\hline 3 & 0,300 & 0,30 & 0,300 & 0,30 & 0,038 & 0,04 & 0,038 & 0,04 \\
\hline 4 & 3,58 & 3,77 & 3,58 & 3,77 & 1,79 & 2,26 & 1,79 & 2,26 \\
\hline 5 & 0,33 & 0,33 & 0,33 & 0,33 & 0,33 & 0,33 & 0,33 & 0,33 \\
\hline 6 & 0,50 & 0,50 & 0,50 & 0,50 & 0,50 & 0,50 & - & - \\
\hline 7 & 250,00 & 12,99 & 250,00 & 12,99 & 250,00 & 12,99 & - & - \\
\hline 8 & 7,666667 & 5,42 & 7,666667 & 5,423033 & 7,666667 & 5,423033 & - & - \\
\hline 9 & 0,14 & 0,14 & 0,05 & 0,05 & 0,05 & 0,05 & 0,05 & 0,05 \\
\hline 10 & 8,72 & 5,70 & 3,49 & 3,71 & 1,74 & 2,21 & 0,87 & 0,87 \\
\hline 11 & 6,10 & 4,93 & 1,22 & 1,43 & 0,61 & 0,61 & 0,61 & 0,61 \\
\hline & $\begin{array}{l}\mathrm{Ci} / \mathrm{Li} \\
\mathrm{Rata} \\
\end{array}$ & 3,42 & & 2,87 & & 2,46 & & 0,61 \\
\hline & $\begin{array}{l}\mathrm{Ci} / \mathrm{Li} \\
\mathrm{Max}\end{array}$ & 12,99 & & 12,99 & & 12,99 & & 2,26 \\
\hline & IP & 9,50 & & 9,41 & & 9,35 & & 1,66 \\
\hline & Category & Polluted & & Polluted & & Polluted & & $\begin{array}{l}\text { Moderatel } \\
\text { y Polluted }\end{array}$ \\
\hline
\end{tabular}

Source: Primary Data Calculation of Excel IP Method

Water quality is calculated using the Pollution Index Method (IP) shown in the table into moderate pollutant status for water class I, II, and III. Designations 9.50, 9.41, and 9.35 are included in common pollutants, while the condition of mild contamination in water class IV is 1.66. Water pollution in the Sikendil River Klepu Village, Pringapus District, Semarang Regency, has resulted in a physical change in the river. In the form of color and foul odors in river water due to industrial effluents and the surrounding community that used to fish to see fish carcasses floating around the river. Because there are complaints and complaints from the community, the Department of the Environment checks and has proven the existence of waste products from industrial activities. As a result, in 2019, one of the companies in Klepu Village had its IPAL permit revoked, but this did not last long because the industry could improve the output of its WWTP (wastewater treatment plant).

\subsection{Management Efforts}

Control efforts in the Sikendil River are based on water quality results, literature studies, and in-depth interviews with the Head of the Environment Department. For environmental damage control in the Semarang Regency and affected communities and farmers around the river, they can identify external factors for pollution control. The results of the Sikendil River control factors are presented in the table. 
Table 3. Control Efforts Stakeholders Made in Sikendil River

\begin{tabular}{|c|c|c|}
\hline No & $\begin{array}{l}\text { River pollution control } \\
\text { aspects }\end{array}$ & Stakeholders undertook control efforts in the Sikendil River \\
\hline 1 & $\begin{array}{l}\text { Sikendil river water } \\
\text { quality conditions }\end{array}$ & $\begin{array}{l}\text { 1. This parameter surpasses the four water quality classes } \\
\text { namely Physical Parameters namely Smell, taste during } \\
\text { chemical parameters such as Nitrate, Nitrite, Free } \\
\text { Chlorine, COD and Total Coli Biological Parameters } \\
\text { 2. In general, the Sikendil river has not been categorized } \\
\text { based on its water class designation, but laboratory tests } \\
\text { show that water class I, II, and III are classified as } \\
\text { Polluted, while the Moderately Polluted status is water } \\
\text { class IV }\end{array}$ \\
\hline 2 & $\begin{array}{l}\text { The role of the Office } \\
\text { of the Environment in } \\
\text { efforts to control river } \\
\text { pollution }\end{array}$ & $\begin{array}{l}\text { 1. Identifying public complaints related to Sikendil river } \\
\text { water pollution } \\
\text { 2. Oversight and coordination through the Sikendil river } \\
\text { care organization } \\
\text { 3. Revocation and issuance of WWTP permits with repair } \\
\text { by the industry } \\
\text { 4. Counseling related to the preservation of the river } \\
\text { 5. Guidance and supervision so that wastewater is not } \\
\text { directly discharged into the river water body, the } \\
\text { discharged liquid waste must not exceed the quality } \\
\text { standard }\end{array}$ \\
\hline 3 & The Role of Industry & $\begin{array}{l}\text { 1. The company is polluting the Sikendil river water. } \\
\text { 2. Repairing and being responsible for the results of } \\
\text { contamination produced } \\
\text { 3. Improve the WWTP (wastewater treatment plant) } \\
\text { disposal process so that it does not exceed the quality } \\
\text { standards before being discharged into the river by } \\
\text { attaching the WWTP (wastewater treatment plant) } \\
\text { waste laboratory test } \\
\text { 4. The company is responsible for the community by } \\
\text { distributing fish seedlings into the stream, taking action } \\
\text { to clean up the river, and participating in preserving the } \\
\text { river's existence. }\end{array}$ \\
\hline 4 & Community Role & $\begin{array}{l}\text { 1. The formation of the organization cares about the } \\
\text { Sikendil river } \\
\text { 2. Public awareness starts to improve } \\
\text { 3. Together with cleaning the river and not contributing to } \\
\text { garbage around the river. }\end{array}$ \\
\hline
\end{tabular}

Source: Analysis of Primary and Secondary Data for 2020

The control is good for the stakeholders. However, several things must be considered in controlling pollution that has been implemented, namely:

1. Consistency is needed from the industry and the community in maintaining the sustainability of the Sikendil River.

2. It is necessary to routinely report the industry from laboratory tests of water quality through each WWTP (wastewater treatment plant) every six months.

3. There is a need for supervision, monitoring from the Semarang Regency Environmental Agency and the local government, both through counseling and training in the industrial waste disposal.

4. Organizations concerned with the Sikendil River must act as trusted intermediaries and connect the community with local government and industry. 


\section{Conclusions}

Sikendil river water quality is polluted for the water class I, II, and III designations respectively at 9.50,9.41, and 9.35 while the Moderately Polluted status at the IV water class is 1.66. Because of the existence of water pollution that has been proven by laboratory tests on the parameters of Physics, Chemistry, and Biology in the Sikendil River, improvement efforts are needed. Efforts that have been made from the Office of the Environment, namely Reprimand, fostering, revocation of WWTP, and sanctions for technical improvements. Efforts made by the industry, namely maintaining the sustainability of river water by paying attention to the discharges' results at WWTP (wastewater treatment plant) before being discharged into the river flow, conducting river cleaning, and spreading fish seeds in the river as a responsibility to the community. At the same time, the community's role is to maintain and participate in overseeing the running of Sikendil during the repair process. The need for consistency, supervision, coordination, and monitoring of various parties keeps the sustainability of the river.

\section{Reference}

1. O. V. D. Paul, M. Richard, Synthesizing Water Quality Indicators From Standardized Geospatial Information To Remedy Water Security Challenges: A Review, Environment International, 119, 220-231 (2018)

2. S. La, Study of Water Quality in Bengalon River on Oil Palm Estate, E3S Web of Conferences, 68 (2018).

3. H. Edris, K. Hassan, W. Chiang, A. Mahdi, Evaluation of Aydughmush River water quality using the National Sanitation Foundation Water Quality Index (NSFWQI), River Pollution Index (RPI), and Forestry Water Quality Index (FWQI), Desalination and Water Treatment, 54 (2015)

4. Peraturan Pemerintah Republik Indonesia Nomor 82 Tahun 2001 Tentang Pengelolaan Kualitas Air Dan Pengendalian Pencemaran Air.

5. A. A. Lutfi, K.I. Maxdoni, Use Of Storet Method And Pollutant Index For Water Quality Assesment Of Cihampelas River, Jurnal Lingkungan Tropis, 6 (2013)

6. L. N. Nelson, Industrial Waste Pollution. London, Addison Wesley Publishing Company (1974)

7. R. Yuda, H. Ahmad, S.G Eko, N. Elza Kajian Penggunaan Metode Ip, Storet, Dan Ccme Wqi Dalam Menentukan Status Kualitas Air, Spatial Wahana Komunikasi Dan Informasi Geografi, 18 (2015)

8. M. Dyah, R. Dwina, Pradono, S. Arwin, River Pollutant Sources Differentiation Using Pollution Index Method (Case Study: Upper Citarum Watershed), Jurnal RISET Geologi dan Pertambangan, 23 (2013)

9. S. Sugiyono, Metode Penelitian Kuantitatif, Kualitatif dan R\&D, Alfabeta, (2016)

10. Keputusan Menteri Lingkungan Hidup Nomor 115 Tentang Pedoman Penentuan Status Mutu Air, (2003) 